\title{
AUTOKORELASI SPASIAL UNTUK IDENTIFIKASI POLA HUBUNGAN KEMISKINAN DI JAWA TIMUR
}

\author{
Rokhana Dwi Bekti \\ Mathematics \& Statistics Department, School of Computer Science, Binus University \\ Jln. K.H. Syahdan No. 9, Palmerah, Jakarta Barat 11480 \\ rokhana_db@binus.ac.id
}

\begin{abstract}
Spatial autocorrelation is a spatial analysis to determine the relationship pattern or correlation among some locations (observation). On the poverty case of East Java, this method will provide important information for analyze the relationship of poverty characteristics in each district or cities. Therefore, in this research performed spatial autocorrelation analysis on the data of East Java's poverty. The method used is moran's I test and Local Indicator of Spatial Autocorrelation (LISA). The analysis showed that by the moran's I test, there is spatial autocorrelation found in the percentage of poor people amount in East Java, both in 2006 and 2007. While by LISA, obtained the conclusion that there is a significant grouping of district or cities.
\end{abstract}

Keywords: spatial autocorrelation, moran's I, LISA, poverty

\begin{abstract}
ABSTRAK
Autokorelasi spasial merupakan salah satu analisis spasial untuk mengetahui pola hubungan atau korelasi antar lokasi (amatan). Pada kasus kemiskinan di Jawa Timur, metode ini akan memberikan informasi penting dalam menganalisis hubungan karakteristik kemiskinan antar wilayah. Oleh karena itu, dalam penelitian ini dilakukan analisis autokorelasi spasial pada data kemiskinan di Jawa Timur. Metode yang digunakan adalah uji moran's I dan Local Indicator of Spatial Autocorrelation (LISA). Hasil analisis menunjukkan bahwa melalui uji moran's I terdapat autokorelasi spasial pada persentase jumlah penduduk miskin di Jawa Timur, baik tahun 2006 maupun 2007. Sementara itu melalui LISA, disimpulkan bahwa terdapat pengelompokan kabupaten/kota yang signifikan.
\end{abstract}

Kata kunci: Autokorelasi Spasial, moran’s I, LISA, kemiskinan 


\section{PENDAHULUAN}

Analisis data spasial merupakan analisis yang berhubungan dengan pengaruh lokasi. Hal ini didasarkan pada hukum pertama tentang geografi dikemukakan oleh Tobler dalam Anselin dan Rey (2010:17) yang menyatakan bahwa segala sesuatu saling berhubungan satu dengan yang lainnya, tetapi sesuatu yang dekat lebih mempunyai pengaruh daripada sesuatu yang jauh. Pada data spasial, seringkali pengamatan di suatu lokasi bergantung pada pengamatan di lokasi lain yang berdekatan (neighboring).

Autokorelasi spasial merupakan salah satu analisis spasial untuk mengetahui pola hubungan atau korelasi antar lokasi (amatan). Beberapa pengujian dalam spasial autokorelasi spasial adalah Moran's I, Rasio Geary's, dan Local Indicator of Spatial Autocorrelation (LISA). Metode ini sangat penting untuk mendapatkan informasi mengenai pola penyebaran karakteristik suatu wilayah dan keterkaitan antar lokasi didalamnya. Selain itu, metode ini juga digunakan untuk identifikasi pemodelan spasial. Beberapa penelitian yang telah menggunakan metode autokorelasi spasial adalah Kissiling dan Carl (2007:5) di bidang pemodelan ekologi, Okwi, et al. (2007:6), serta Bekti dan Sutikno (2010:4) dalam analisis autokorelasi data kemiskinan.

Kemiskinan masih menjadi salah satu permasalahan utama di negara Indonesia, sehingga perlu terus dikaji pola penyebarannya dan dilakukan upaya untuk menyelesaikannya. Berbagai upaya telah dilakukan melalui pemberian program-program pengentasan kemiskinan. Dalam tujuan Millenium Development Goals (MDGs), disebutkan juga salah satu tujuannya adalah mengurangi kemiskinan ekstrim sejumlah 50\% hingga tahun 2015.

BPS Propinsi Jawa Timur (2012) menyebutkan bahwa penduduk miskin Jawa Timur pada bulan September 2011 sebanyak 5,227 juta (13,85 persen) atau turun 2,41 persen dibandingkan dengan jumlah penduduk miskin pada bulan Maret 2011 yang sebesar 5,356 juta (14,23 persen). Di beberapa lokasi di Jawa Timur, seperti beberapa kabupaten di kepulauan Madura memiliki jumlah penduduk miskin relatif sama dan lebih tinggi dibandingkan dengan kabupaten/kota lainnya. Berdasarkan hal tersebut, dapat dikatakan bahwa penyebaran angka kemiskinan di beberapa lokasi menunjukkan pembentukan pola-pola tertentu. Adanya pola-pola ini juga menunjukkan adanya hubungan antar lokasi.

Karakteristik sosial, ekonomi, sumberdaya alam, penduduk, dan pendidikan yang berbeda di setiap lokasi yang berbeda menimbulkan permasalahan kemiskinan yang berbeda pula. Lokasi yang memiliki karakteristik yang sama akan memiliki permasalahan kemiskinan yang hampir sama. Selain itu, lokasi yang berdekatan juga akan memiliki permasalahan kemiskinan yang hampir sama. Berdasarkan kajian teori dan permasalahan yang ada, pada penelitian ini dilakukan analisis autokorelasi spasial untuk mengetahui hubungan karakteristik kemiskinan antar lokasi di Jawa Timur. Informasi ini sangat penting untuk membantu menganalisis hubungan karakteristik kemiskinan antar wilayah, faktor-faktor yang mempengaruhinya serta dapat direkomendasikan untuk menentukan suatu kebijakan yang terpadu antar wilayah.

\section{METODE}

Data yang digunakan dalam penelitian ini adalah jumlah penduduk miskin Jawa Timur 20062007 yang diperoleh dari data Badan Pusat Statistika (BPS). Peta lokasi dan kode kabupaten/kota disajikan pada Gambar 1 dan Tabel 1. 


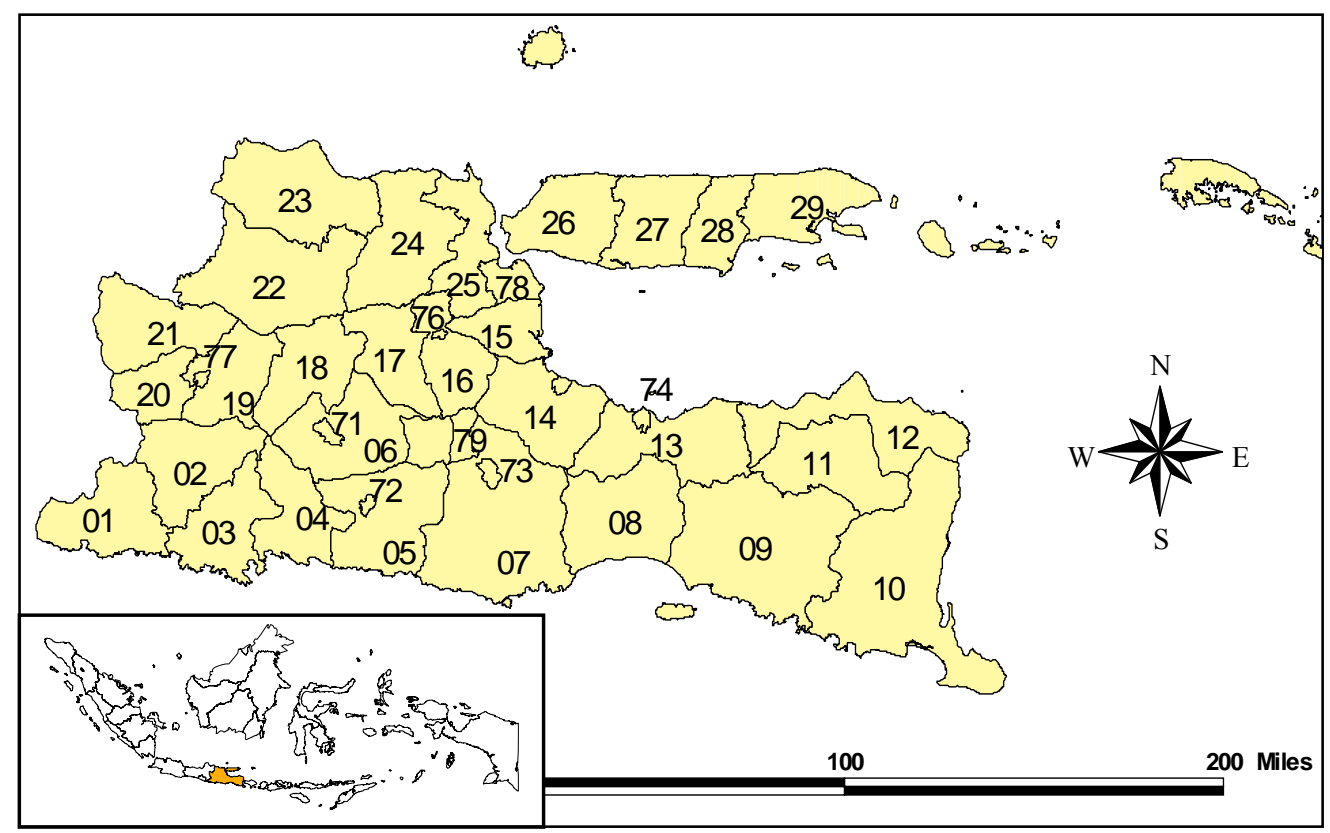

Gambar 1. Lokasi penelitian.

Tabel 1

Kode Kabupaten/Kota di Jawa Timur

\begin{tabular}{|c|c|c|c|c|c|c|c|c|c|c|c|}
\hline No & & ab/Kota & No & & Kab/Kota & No & & b/Kota & No & \multicolumn{2}{|c|}{ Kab/Kota } \\
\hline 01 & Kab. & Pacitan & 11 & Kab. & Bondowoso & 21 & Kab. & Ngawi & 72 & Kota & Blitar \\
\hline 02 & Kab. & Ponorogo & 12 & Kab. & Situbondo & 22 & Kab. & Bojonegoro & 73 & Kota & Malang \\
\hline 03 & Kab. & Trenggalek & 13 & Kab. & Probolinggo & 23 & Kab. & Tuban & 74 & Kota & Probolinggo \\
\hline 04 & Kab. & Tulungagung & 14 & Kab. & Pasuruan & 24 & Kab. & Lamongan & 75 & Kota & Pasuruan \\
\hline 05 & Kab. & Blitar & 15 & Kab. & Sidoarjo & 25 & Kab. & Gresik & 76 & Kota & Mojokerto \\
\hline 06 & Kab. & Kediri & 16 & Kab. & Mojokerto & 26 & Kab. & Bangkalan & 77 & Kota & Madiun \\
\hline 07 & Kab. & Malang & 17 & Kab. & Jombang & 27 & Kab. & Sampang & 78 & Kota & Surabaya \\
\hline 08 & Kab. & Lumajang & 18 & Kab. & Nganjuk & 28 & Kab. & Pamekasan & 79 & Kota & Batu \\
\hline 09 & Kab. & Jember & 19 & Kab. & Madiun & 29 & Kab. & Sumenep & & & \\
\hline 10 & Kab. & Banyuwangi & 20 & $\mathrm{Kab}$. & Magetan & 71 & Kota & Kediri & & & \\
\hline
\end{tabular}

Sementara itu, metode analisis melalui tahapan eksplorasi data melalui peta tematik dilanjutkan dengan analisis autokorelasi spasial, yaitu Moran's I dan LISA. Pembobot yang digunakan adalah kode biner dan persinggungan sisi (Rook Contiguity).

\section{Moran’s I}

Koefisien Moran's I merupakan pengembangan dari korelasi pearson pada data univariate series. Koefisien Moran's I digunakan untuk uji dependensi spasial atau autokorelasi antar amatan atau lokasi.

Hipotesis yang digunakan adalah:

$\mathrm{H}_{\mathrm{o}} \mathrm{I}=0$ (tidak ada autokorelasi antar lokasi)

$\mathrm{H}_{1:} \mathrm{I} \neq 0$ (ada autokorelasi antar lokasi) 
Statistik uji (Lee dan Wong, 2001):

$Z_{\text {hitung }}=\frac{I-\mathrm{I}_{\mathrm{o}}}{\sqrt{\operatorname{var}(\mathrm{I})}} \sim N(0,1)$

di mana nilai moran's I:

$$
I=\frac{\mathrm{n}}{\sum_{\mathrm{i}=1}^{\mathrm{n}} \sum_{\mathrm{j}=1}^{\mathrm{n}} w_{\mathrm{ij}}} \frac{\sum_{\mathrm{i}=1}^{\mathrm{n}} \sum_{\mathrm{j}=1}^{\mathrm{n}} w_{\mathrm{ij}}\left(x_{\mathrm{i}}-\bar{x}\right)\left(x_{\mathrm{j}}-\bar{x}\right)}{\sum_{\mathrm{i}=1}^{\mathrm{n}}\left(x_{\mathrm{i}}-\bar{x}\right)^{2}}
$$

Keterangan:

$\begin{array}{ll}x_{\mathrm{i}} & =\text { data variabel lokasi ke-i }(\mathrm{i}=1,2, \ldots, \mathrm{n}) \\ x_{\mathrm{j}} & =\text { data variabel lokasi ke-j }(\mathrm{j}=1,2, \ldots, \mathrm{n}) \\ \bar{X} & =\text { rata-rata data } \\ w & =\text { matrix pembobot } \\ \operatorname{var}(I) & =\text { varians Moran's I } \\ \underline{E}(I) & =\text { expected value Moran's I }\end{array}$

$$
\begin{aligned}
& \mathrm{E}(I)=\mathrm{I}_{o}=-\frac{1}{\mathrm{n}-1} \\
& \operatorname{var}(I)=\frac{\mathrm{n}^{2} S_{1}-\mathrm{n} S_{2}+3 S_{o}^{2}}{\left(\mathrm{n}^{2}-1\right) S_{o}^{2}} \\
& S_{1}=\frac{1}{2} \sum_{\mathrm{i} \neq \mathrm{j}}^{\mathrm{n}}\left(w_{\mathrm{ji}}+w_{\mathrm{ij}}\right)^{2} \quad S_{2}=\sum_{\mathrm{i}=1}^{\mathrm{n}}\left(w_{\mathrm{io}}+w_{\mathrm{oi}}\right)^{2} \\
& S_{o}=\sum_{\mathrm{i}=1}^{\mathrm{n}} \sum_{\mathrm{j}=1}^{\mathrm{n}} w_{\mathrm{ij}} \quad w_{\mathrm{io}}=\sum_{\mathrm{j}=1}^{\mathrm{n}} w_{\mathrm{ij}} \quad w_{\mathrm{oi}}=\sum_{\mathrm{j}=1}^{\mathrm{n}} w_{\mathrm{ji}}
\end{aligned}
$$

Pengambilan keputusan Ho ditolak atau ada autokorelasi antar lokasi jika $\left|Z_{\text {hitung }}\right|>Z_{\alpha / 2}$. Nilai dari indeks I adalah antara -1 dan 1 . Apabila $\mathrm{I}>\mathrm{I}_{0}$, data memiliki autokorelasi positif. Jika $\mathrm{I}<\mathrm{I}_{0}$, data memiliki autokorelasi negatif.

Pola pengelompokan dan penyebaran antar lokasi dapat disajikan dengan Moran's Scatterplot (lihat Gambar 2), yang menunjukkan hubungan antara nilai amatan pada suatu lokasi (distandarisasi) dengan rata-rata nilai amatan dari lokasi-lokasi yang bertetanggaan dengan lokasi yang bersangkutan (Lee dan Wong, 2001). Scatterplot tersebut terdiri atas empat kuadran (Perobelli dan Haddad, 2003), yaitu:

Kuadran I (High-High), menunjukkan lokasi yang mempunyai nilai amatan tinggi dikelilingi oleh lokasi yang mempunyai nilai amatan tinggi.

Kuadran II (Low-High), menunjukkan lokasi yang mempunyai nilai amatan rendah dikelilingi oleh lokasi yang mempunyai nilai amatan tinggi.

Kuadran III (Low-Low), menunjukkan lokasi yang mempunyai nilai amatan rendah dikelilingi oleh lokasi yang mempunyai nilai amatan rendah.

Kuadran IV (High-Low), menunjukkan lokasi yang mempunyai nilai amatan tinggi dikelilingi oleh lokasi yang mempunyai nilai amatan rendah. 


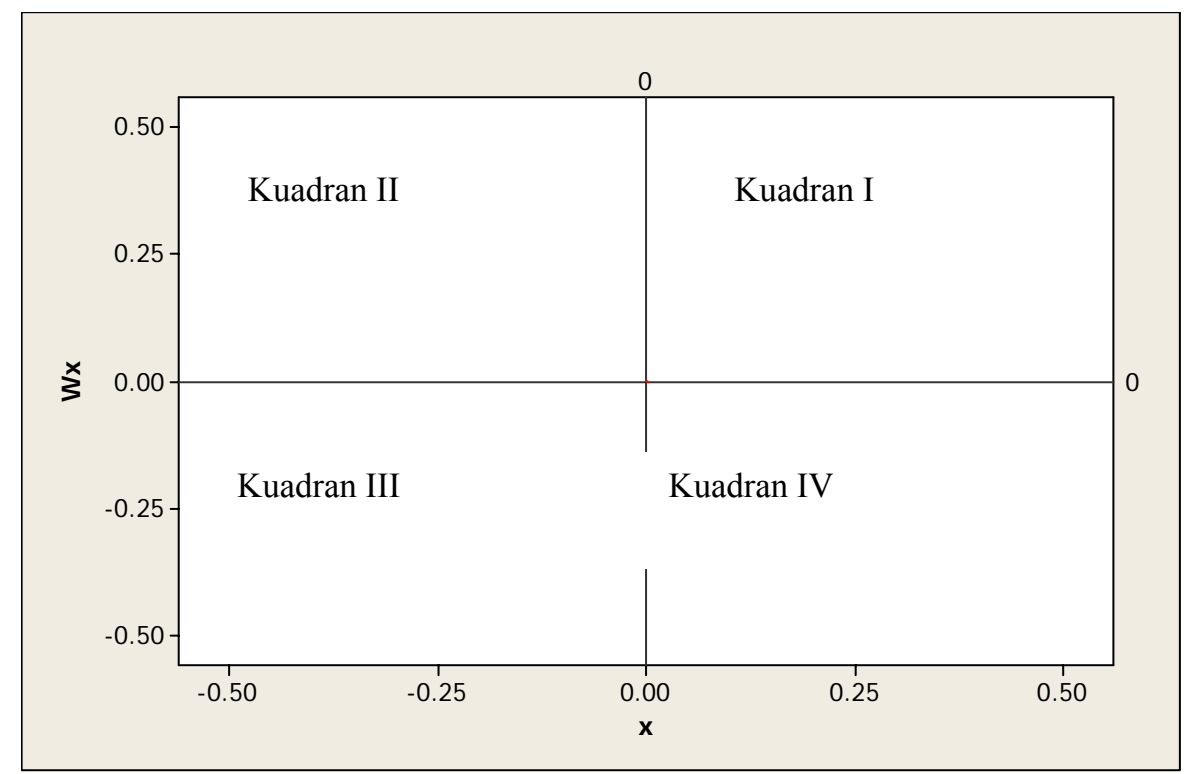

Gambar 2. Moran’s Scatterplot.

\section{Local Indicator of Spatial Autocorrelation (LISA)}

Moran's I juga dapat digunakan untuk pengidentifikasian koefisien autocorrelation secara lokal (local autocorrelation) atau korelasi spasial pada setiap daerah. Semakin tinggi nilai lokal Moran's, memberikan informasi bahwa wilayah yang berdekatan memiliki nilai yang hampir sama atau membentuk suatu penyebaran yang mengelompok. Identifikasi Moran's I tersebut adalah Local Indicator of Spatial Autocorrelation (LISA), yang indeksnya dinyatakan dalam (Lee \& Wong, 2001) seperti pada persamaan (3).

$$
\mathbf{I}_{i}=z_{i} \sum_{\mathrm{i}=1}^{\mathrm{n}} w_{\mathrm{ij}} z_{\mathrm{j}}
$$

$z_{i}$ dan $z_{j}$ adalah $z_{i}=\frac{\left(x_{i}-\bar{x}\right)}{\sigma_{x}} \quad z_{j}=\frac{\left(x_{j}-\bar{x}\right)}{\sigma_{x}}$

$\sigma_{x}$ adalah nilai standar deviasi dari variabel $x$.

Pengujian terhadap parameter $\mathrm{I}_{\mathrm{i}}$ dapat dilakukan sebagai berikut:

$\mathrm{H}_{\mathrm{o}:} \mathrm{I}_{\mathrm{i}}=0$ (tidak ada autokorelasi antar lokasi)

$\mathrm{H}_{1:} \mathrm{I}_{\mathrm{i}} \neq 0$ (ada autokorelasi antar lokasi)

Statistik uji:

$$
Z_{\text {hitung }}=\frac{I_{i}-E\left(I_{i}\right)}{\sqrt{\operatorname{var}\left(\mathbf{I}_{\mathbf{i}}\right)}}
$$

Keterangan:

$w \quad=$ matrix pembobot

$\operatorname{var}(I)=$ varians Moran's I

$E(I)=$ expected value Moran's I 


$$
\begin{array}{ll}
\operatorname{var}\left(I_{i}\right)=w_{i .}^{(2)} \frac{\left(n-\frac{m_{4}}{m_{2}^{2}}\right)}{n-1}-2 w_{i(k h)} \frac{\left(2 m_{4} / m_{2}^{2}-n\right)}{(n-1)(n-2)}-\frac{w_{i,}^{2}}{(n-1)^{2}} \\
w_{i .}^{(2)}=\sum_{j=1}^{n} w_{i j}^{2}, \quad i \neq j & w_{i .}^{2}=\left(\sum_{j=1}^{n} w_{i j}\right)^{2} \\
w_{i(k h)}=\sum_{k \neq i}^{n} \sum_{h \neq i}^{n} w_{i k} w_{i h} & E\left(I_{i}\right)=-\frac{w_{i .}}{n-1}
\end{array}
$$

Pengujian ini akan menolak Ho jika $\left|Z_{\text {hitung }}\right|>Z_{\alpha / 2}$ atau P value $<\alpha=5 \%$. Positif autokorelasi spasial megindikasikan bahwa antar lokasi pengamatan memiliki keeratan hubungan.

\section{Pembobot}

Hubungan kedekatan (neighbouring) antar lokasi dinyatakan dalam matrik pembobot $\mathbf{W}$. Elemen-elemen matrik tersebut adalah $w_{i j}$ yang menunjukkan ukuran hubungan lokasi ke-i dan ke-j. Lokasi yang dekat dengan lokasi yang diamati diberi pembobot besar, sedangkan yang jauh diberi pembobot kecil. Pemberian koding pembobotan menurut Bivand (2006) dalam Kissling dan Carl (2008:3) di antaranya adalah kode biner:

$$
w_{\mathrm{ij}}=\left\{\begin{array}{l}
1, \text { untuk i dan } j \text { yang berdekatan } \\
0 \text { untuk lainnya }
\end{array}\right.
$$

Sementara itu jenis pembobotan area adalah persinggungan tepi (Linear Contiguity), persinggungan sisi (Rook Contiguity), persinggungan sudut (Bhisop Contiguity), dan lain-lain

\section{HASIL DAN PEMBAHASAN}

Jumlah penduduk miskin di Jawa Timur tahun 2006 dan 2007 adalah 21,09 persen (7.678,1 juta jiwa) dan 9,71 persen (7.155,3 juta jiwa). Pada tahun 2006, Kabupaten Sampang memiliki persentase tertinggi, yaitu 41,03 persen. Selanjutnya Kabupaten Sumenep (34,86 persen) dan Pamekasan (34,14 persen). Dapat diketahui bahwa kabupaten-kabupaten tersebut saling berdekatan dan berlokasi di Pulau Madura. Seperti halnya di beberapa kabupaten lainnya seperti Kabupaten Bojonegoro, Lamongan, Gresik, Jombang, Nganjuk, Madiun, dan Ngawi yang memiliki persentase antara 20,01-30,00 persen. Kabupaten-kabupaten tersebut berlokasi di Jawa Timur bagian utara. Kemudian Kabupaten Kediri, Malang, Blitar, dan Tulungagung yang berlokasi di Jawa timur bagian selatang, memiliki persentase 10,01-20,00 persen.

Pada tahun berikutnya, persentase penduduk miskin juga membentuk pola-pola mengelompok pada lokasi-lokasi tertentu. Pengelompokan kabupaten/kota yang ada juga hampir sama. Kabupaten Sampang masih memiliki persentase yang tinggi, yaitu 39,42 persen. Selanjutnya Kabupaten Bangkalan, Sumenep, dan Pamekasan di Pulau Madura memiliki persentase 30,01-40,00. Detail persentase penduduk miskin di setiap kabupaten/kota di Jawa Timur disajikan pada Gambar 3. Berdasarkan lokasi dan persentase yang hampir sama tersebut dapat dikatakan bahwa angka 
kemiskinan membentuk suatu pola penyebaran yang mengelompok pada beberapa lokasi. Untuk membuktikan hal ini perlu di uji melalui autokorelasi spasial Moran's I dan LISA.

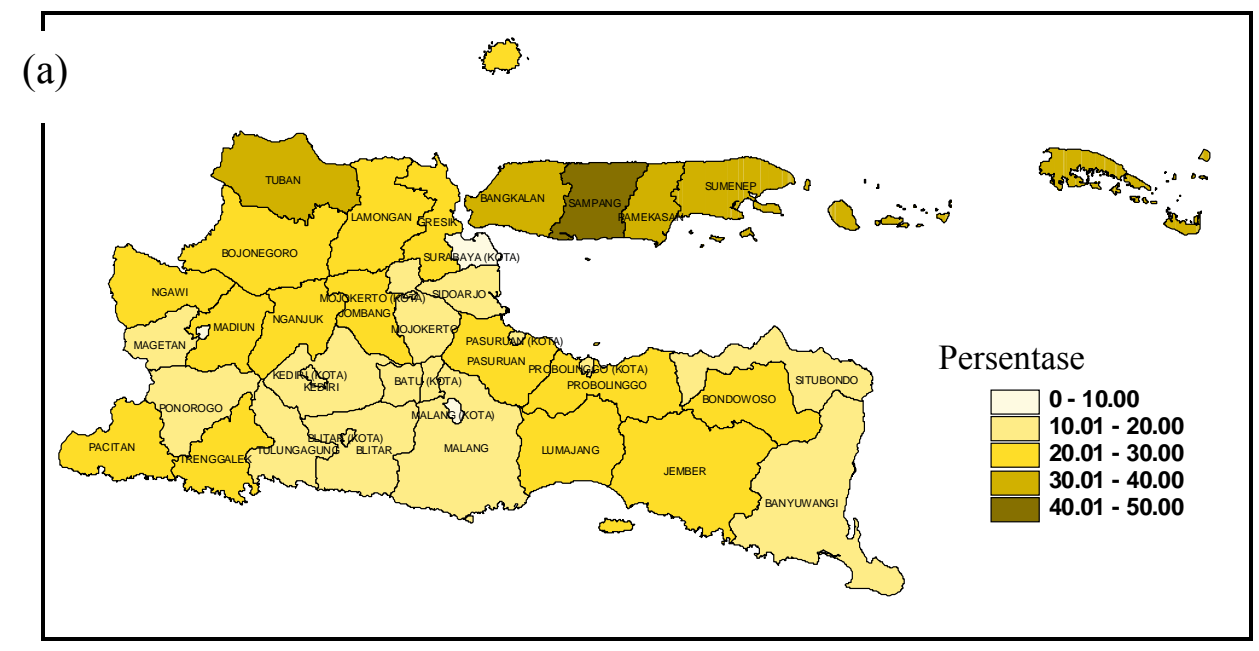

(b)

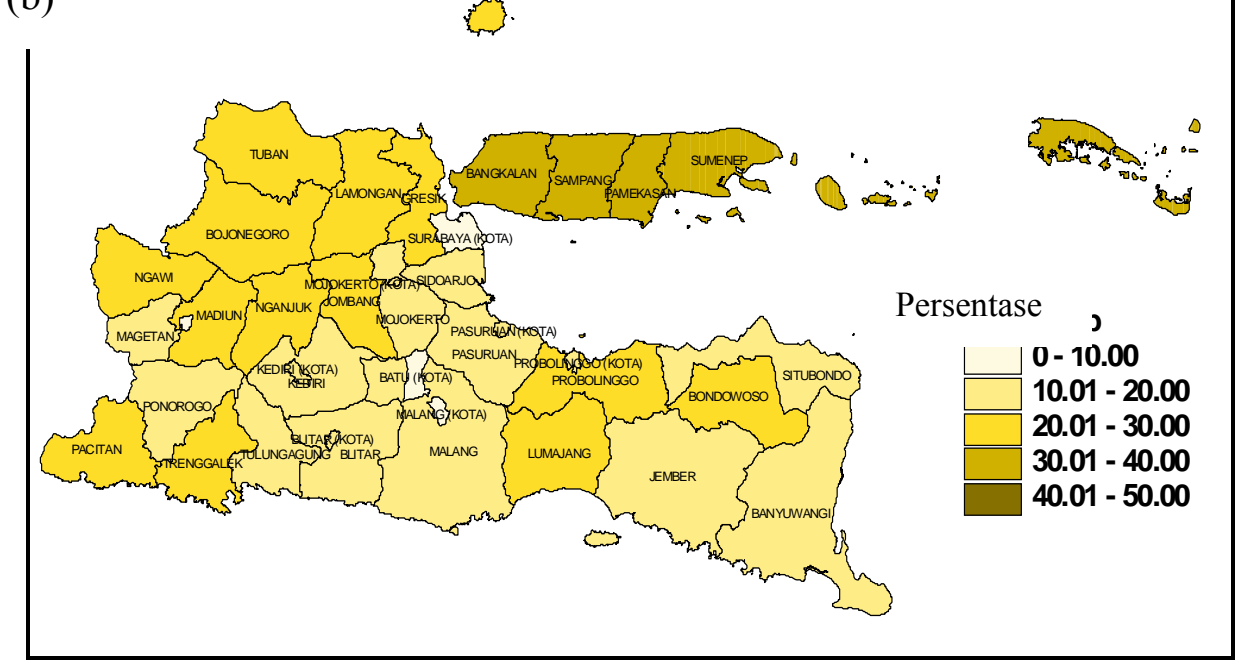

Gambar 3. Pola Persebaran Presentase Penduduk Miskin Jawa Timur (a) Tahun 2006, (b) Tahun 2007 (Sumber: Diolah dari BPS)

\section{Nilai Moran’s I}

Berdasarkan hasil pengujian autokorelasi spasial dengan Moran's I (Tabel 2) dengan tingkat signifikansi 5 persen, diketahui bahwa terdapat autokorelasi spasial pada persentase penduduk miskin di Jawa Timur, baik tahun 2006 maupun 2007. Hal ini ditunjukkan oleh nilai $\left|Z_{\text {hitung }}\right|>1.96$. Autokorelasi spasial ini menunjukkan bahwa ada keterkaitan atau hubungan nilai persentase penduduk miskin antar kabupaten/kota di Jawa Timur. Seperti pada identifikasi sebelumnya, ada pengelompokan pada beberapa lokasi. Angka Moran's I pada tahun 2006 dan 2007 adalah 0,5116 dan 0.5434 yang lebih besar dari $\mathrm{I}_{\mathrm{o}}=-0,027$. Hal ini menunjukkan ada autokorelasi positif atau pola yang mengelompok dan memiliki kesamaan karakteristik pada lokasi yang berdekatan. 
Tabel 2

Pengujian Moran's I

\begin{tabular}{|c|c|c|}
\hline Tahun & Moran's I & $\mathbf{Z}_{\text {hitung }}$ \\
\hline - 2006 & 0.5116 & -13.60101 \\
\hline $\begin{array}{l}-\quad 2007 \\
\end{array}$ & 0.5434 & 4.7023908 \\
\hline
\end{tabular}

Gambar 4 merupakan Moran's scatterplot yang menunjukkan pola hubungan antara persentase penduduk miskin pada suatu kabupaten/kota dengan kabupaten/kota lain. Kabupaten/Kota yang berada masing-masing kuadran tahun 2006 di antaranya:

Kuadran 1: Bangkalan, Sampang, Pamekasan, Sumenep, Tuban, Bojonegoro, Lamongan, Ngawi, Pacitan, Trenggalek, Jombang, dan Nganjuk. Kabupaten ini memiliki nilai persentase penduduk miskin tinggi dan berdekatan dengan kabupaten lain yang memiliki nilai persentase penduduk miskin tinggi pula.

Kuadran 2: Ponorogo, Tulungagung, Jember, Banyuwangi, Situbondo, Kota Probolinggo, Kota Pasuruan, dan Kota Madiun. Kabupaten/Kota ini memiliki nilai persentase penduduk miskin rendah akan berdekatan dengan kabupaten/kota lain yang memiliki nilai persentase penduduk miskin tinggi.

Kuadran 3: Blitar, Kediri, Malang, Sidoarjo, Mojokerto, Magetan, Kota Kediri, Kota Malang, Kota Mojokerto, Kota Madiun, Kota Surabaya, dan Kota Blitar. Kabupaten ini memiliki nilai persentase penduduk miskin rendah berdekatan dengan kabupaten lain yang memiliki nilai persentase penduduk miskin rendah pula.

Kuadran 4: Bondowoso, Probolinggo, Pasuruan, Madiun, dan Gresik. Kabupaten ini memiliki nilai persentase penduduk miskin tinggi akan berdekatan dengan kabupaten lain yang memiliki nilai persentase penduduk miskin rendah.
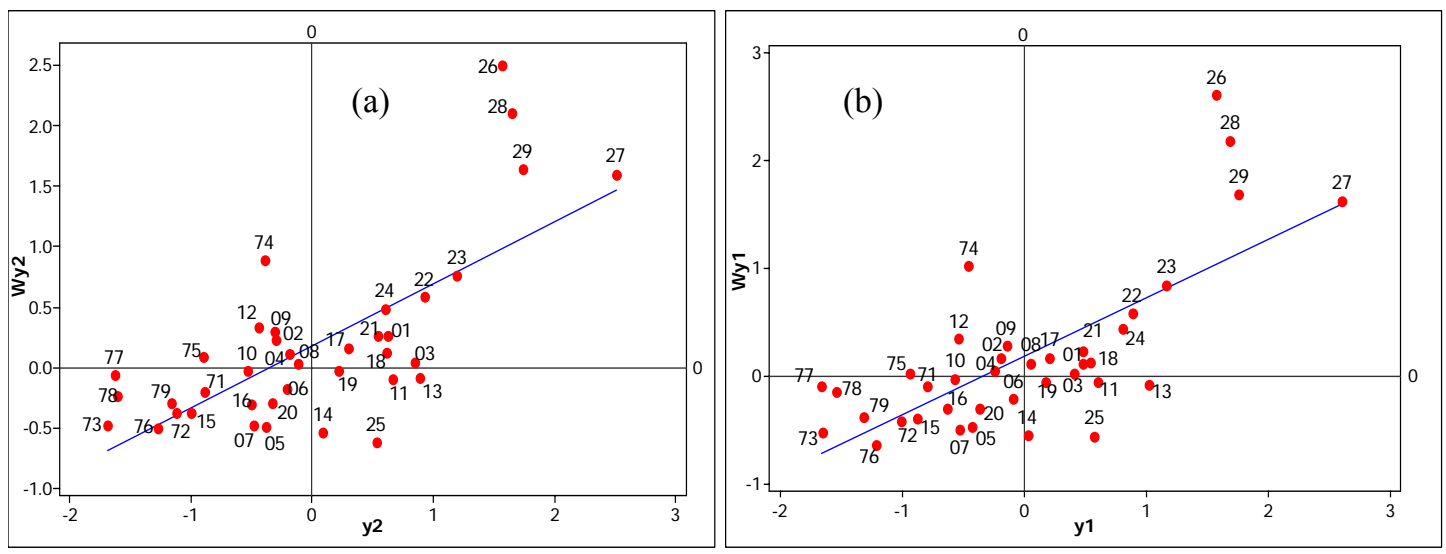

Gambar 4. Moran's Scatterplot Persentase Penduduk Miskin Jawa Timur

(a) Tahun 2006, (b) Tahun 2007.

\section{Nilai Local Indicator of Spatial Autocorrelation (LISA)}

Hasil pengujian Moran's I menunjukkan bahwa terdapat autokerelasi atau hubungan spasial persentase kemiskinan di Jawa Timur. Selanjutnya pada Moran's scatterplot juga digambarkan bagaimana pola hubungan antar kabupaten/kota yang ada. Untuk mengetahui signifikansi autokorelasi 
spasial secara lokal adalah melalui LISA. Dari pengujian ini akan didapatkan signifikansi hubungan secara lokal pada masing-masing kabupaten/kota.

Tabel 3 menunjukkan nilai Moran's I lokal dan Pvalue pengujian LISA. Dapat diketahui bahwa baik pada tahun 2006 maupun 2007, terdapat pengelompokan kabupaten/kota yang signifikan memiliki autokorelasi dengan kabupaten/kota lainnya. Seperti pada Kabupaten Bangkalan, Sampang, dan Pamekasan memiliki moran's I sangat tinggi dan signifikan pada $\alpha=5$ persen, yaitu 4,$168 ; 4,168$; dan 3,527. Sementara itu, Sumenep memiliki moran's I tinggi pula dan signifikan pada $\alpha=10 \%$, yaitu 2,886. Kabupaten yang memiliki moran's I relativf tinggi dengan kabupaten lain dan signifikan pada $\alpha=10$ persen adalah Tuban, Lamongan, Gresik, Sidoarjo, Mojokerto, dan Blitar. Kabupaten-kabupatenkabupaten ini juga berlokasi saling berdekatan. Pola tingkat signifikansi moran's lokal disajikan pada Gambar 5.

Tabel 3

Pengujian LISA

\begin{tabular}{|c|c|c|c|c|c|c|c|c|c|}
\hline \multirow{2}{*}{ Kab/Kota } & \multicolumn{2}{|c|}{2006} & \multicolumn{2}{|c|}{2007} & \multirow[b]{2}{*}{ Kab/Kota } & \multicolumn{2}{|c|}{2006} & \multicolumn{2}{|c|}{2007} \\
\hline & I & Pvalue & I & Pvalue & & I & Pvalue & I & Pvalue \\
\hline Pacitan & 0.0435 & 0.424 & 0.0625 & 0.402 & Kota Malang & 0.3617 & 0.498 & 0.8396 & 0.368 \\
\hline Ponorogo & -0.0696 & 0.26 & -0.0314 & 0.278 & Kota Probolinggo & -0.3525 & 0.14 & -0.4565 & 0.118 \\
\hline Trenggalek & 0.0073 & 0.47 & 0.0136 & 0.458 & Kota Pasuruan & -0.08 & 0.42 & -0.0398 & 0.48 \\
\hline Tulungagung & -0.0065 & 0.5 & 0.0017 & 0.46 & Kota Mojokerto & 0.6586 & 0.286 & 0.7356 & 0.264 \\
\hline Lumajang & -0.0222 & 0.342 & 0.0094 & 0.416 & Kota Madiun & 0.1047 & 0.416 & 0.1342 & 0.466 \\
\hline Bondowoso & -0.036 & 0.49 & -0.0213 & 0.476 & Kota Surabaya & 0.3847 & 0.372 & 0.2063 & 0.452 \\
\hline Pasuruan & -0.0428 & 0.098 & -0.023 & 0.082 & Kota Batu & 0.2494 & 0.352 & 0.4668 & 0.252 \\
\hline Jombang & 0.056 & 0.296 & 0.0136 & 0.426 & Blitar & 0.1678 & 0.17 & 0.0466 & 0.124 \\
\hline Nganjuk & 0.0731 & 0.356 & 0.01224 & 0.47 & Kediri & 0.0274 & 0.37 & 0.10399 & 0.362 \\
\hline Madiun & -0.0076 & 0.476 & -0.0067 & 0.468 & Mojokerto & 0.1385 & 0.19 & 0.1684 & 0.184 \\
\hline Magetan & 0.1023 & 0.284 & 0.0992 & 0.24 & Banyuwangi & -0.0174 & 0.498 & 0.0253 & 0.47 \\
\hline Ngawi & 0.146 & 0.278 & 0.1214 & 0.312 & Gresik & -0.3361 & 0.1 & -0.3159 & 0.136 \\
\hline Bojonegoro & 0.5372 & 0.066 & 0.5168 & 0.064 & Jember & -0.0265 & 0.346 & -0.0341 & 0.282 \\
\hline Tuban & 0.9174 & 0.12 & 1.0108 & 0.116 & Malang & 0.0988 & 0.09 & 0.258 & 0.046 \\
\hline Lamongan & 0.2931 & 0.116 & 0.3706 & 0.132 & Probolinggo & -0.0492 & 0.464 & -0.08 & 0.462 \\
\hline Bangkalan & 4.1683 & 0.034 & 4.1216 & 0.032 & Sampang & 4.1683 & 0.008 & 4.271 & 0.004 \\
\hline Pamekasan & 3.5272 & 0.004 & 3.7039 & 0.002 & Sidoarjo & 0.3802 & 0.196 & 0.3223 & 0.198 \\
\hline Kota Kediri & 0.1901 & 0.488 & 0.5966 & 0.268 & Situbondo & -0.1493 & 0.288 & -0.1712 & 0.296 \\
\hline Kota Blitar & 0.4339 & 0.35 & 0.0738 & 0.478 & Sumenep & 2.8861 & 0.082 & 2.9877 & 0.054 \\
\hline Kota Malang & 0.3617 & 0.498 & 0.8396 & 0.368 & & & & & \\
\hline
\end{tabular}




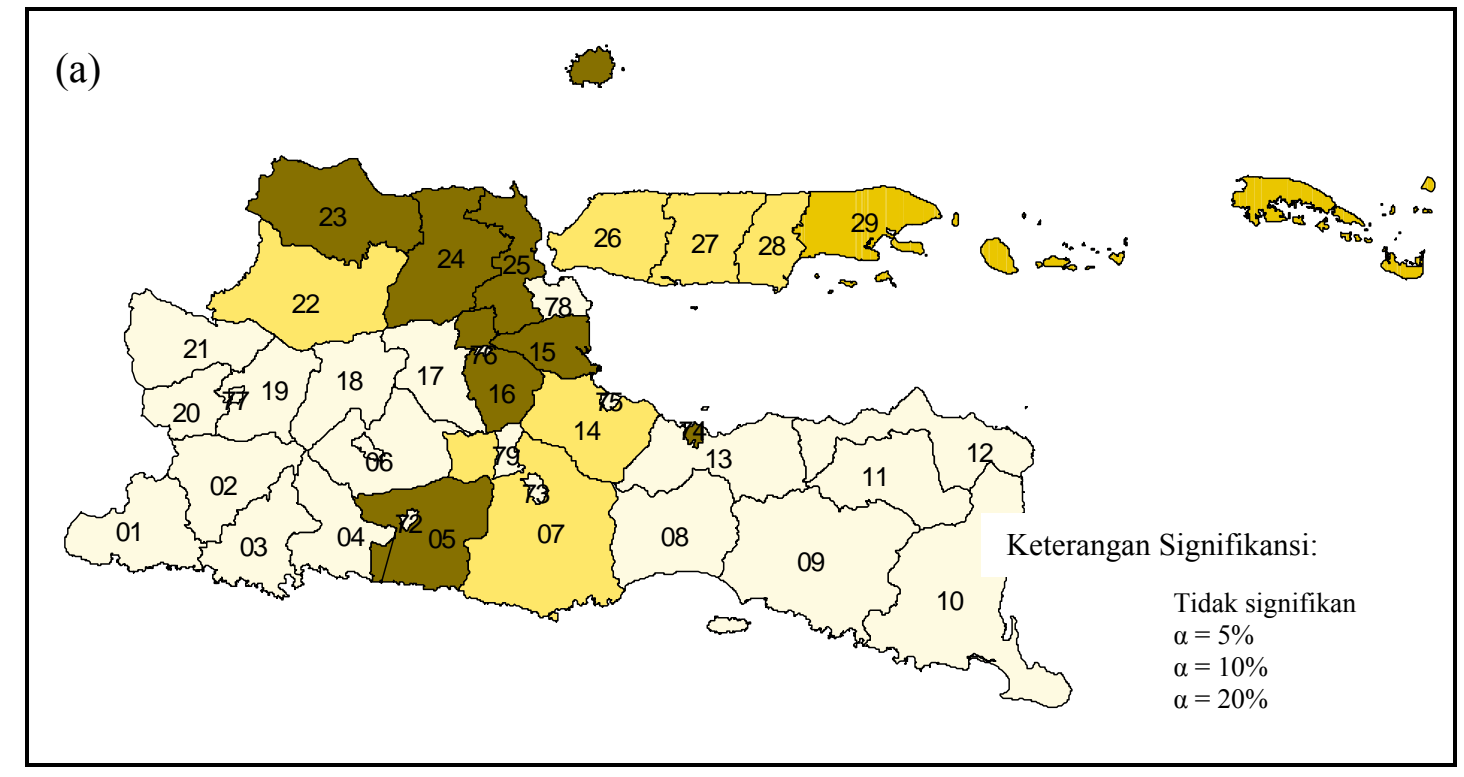

(b)

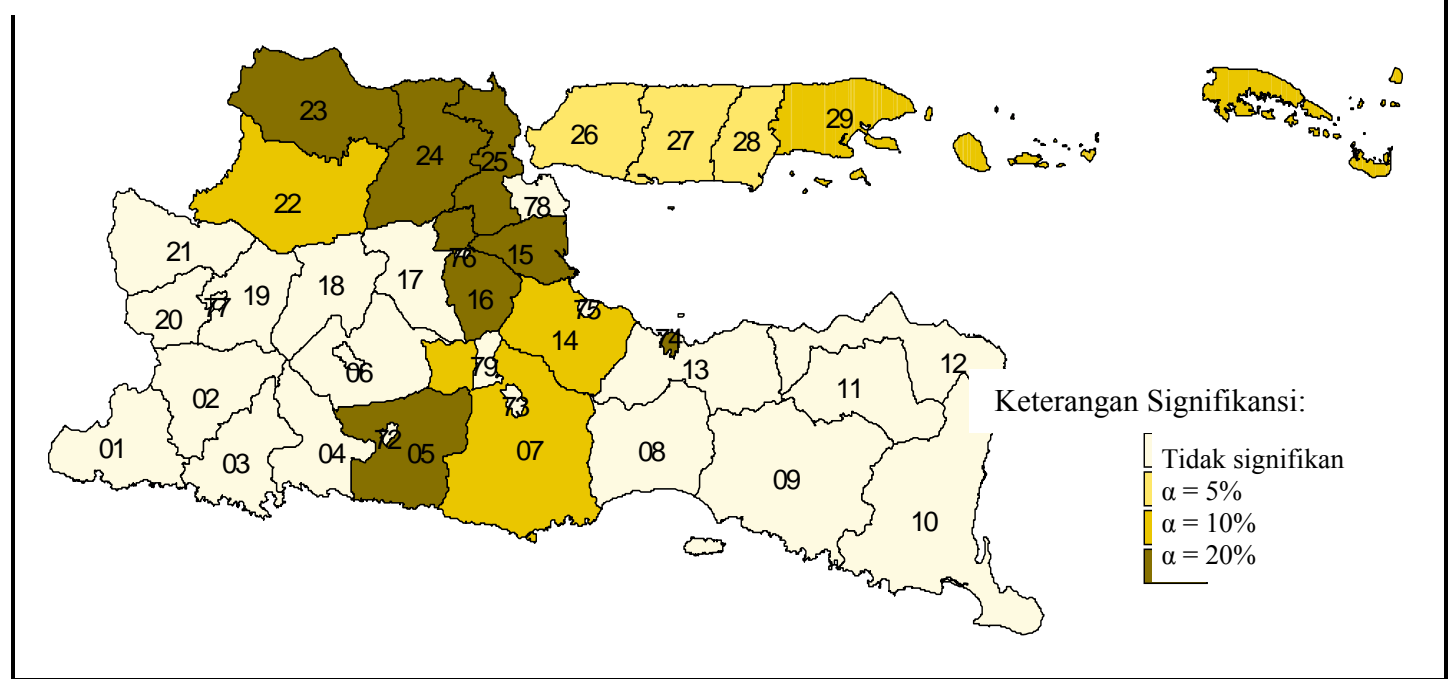

Gambar 5. Pola signifikansi pengujian LISA persentase penduduk miskin Jawa Timur (a) tahun 2006, (b) tahun 2007.

\section{PENUTUP}

Berdasarkan hasil analisis dan pembahasan melalui moran's I didapat kesimpulan bahwa terdapat autokorelasi spasial pada persentase jumlah penduduk miskin di Jawa Timur, baik tahun 2006 maupun 2007. Angka Moran's I pada tahun 2006 dan 2007 adalah 0,5116 dan 0.5434 yang menunjukkan ada autokorelasi positif atau pola yang mengelompok dan memiliki kesamaan karakteristik pada lokasi yang berdekatan. Sementara itu melalui LISA, didapat kesimpulan bahwa ada pengelompokan kabupaten/kota yang signifikan. 


\section{DAFTAR PUSTAKA}

Anselin, Luc \& Rey, Sergio J. (2010). Perspectives on Spatial Data Analysis. New york: Springer.

Badan Pusat Statistik Jawa Timur. (2012). Profil Kemiskinan di Jawa Timur September 2011. Surabaya: BPS Provinsi Jawa Timur

Bekti, R. B. \& Sutikno. (2010). Permodelan spasial pada hubungan antara aset kehidupan masyarakat jawa timur dalam memenuhi kebutuhan pangan terhadap kemiskinan. Seminar Nasional Pasca Sarjana X. Surabaya: Pasca Sarjana Institut Teknologi Sepuluh Nopember. hal. VI-38.

Kissling, W. D. dan Carl, G. (2008). Spatial autocorrelation and the selection of simultaneous autoregressive models. Global Ecology and Biogeography, 17, 59-71.

Lee, J. dan Wong, D. W. S. (2001). Statistical Analysis with Arcview GIS. New York: John Wiley and Sons.

Okwi, P.O., Ndeng'e G, Kristjanson, P., Arunga, M., Notenbaert, A., Omolo, A., Henninger, N., Benson, T., Kariuki, P., \& Ownor, J. (2007). Spatial determinants of poverty in rural Kenya. Diakses 1 November 2011 dari www.pnas.org_cgi_doi_10.1073_pnas.0611107104

Perobelli, F. S., dan Haddad, E. (2003). Brazilian Interregional Trade (1985-1996): An Exploratory Spatial Data Analysis. Diakses 10 Januari 2011 dari http://www.anpec.org.br/encontro2003/artigos/E18.pdf. 